\title{
UPAYA MENINGKATKAN PERILAKU ORGANIZATIONAL CITIZENSHIP BEHAVIOR (OCB) PADA KARYAWAN PT. POS INDONESIA PERSERO SURAKARTA
}

\author{
Alean Kistiani Hegy Suryana ${ }^{1)}$ \\ Milka Susana Theorupun ${ }^{2)}$ \\ Fakultas Ekonomi Universitas Boyolali \\ www.uby.ac.id
}

\begin{abstract}
ABSTRAK
Tujuan penelitian ini adalah untuk menguji dan menganalisis pengaruh Kecerdasan Emosional dan Motivasi Kerja terhadap Organizational Citizenship behavior (OCB) dengan Kepuasan Kerja sebagai Pemediasi (Studi Pada Karyawan PT. Pos Indonesia Persero Surakarta). Subjek penelitian ini adalah 168 Karyawan PT. Pos Indonesia Persero Surakarta. Teknik pengambilan sampel dilakukan dengan probability sampling. Metode analisis data menggunakan Regresi Linier Berganda dengan analisis jalur. Hasil Uji Hipotesis menunjukkan Kecerdasan Emosional berpengaruh signifikan terhadap Kepuasan Kerja, Motivasi Kerja berpengaruh signifikan terhadap Kepuasan Kerja, Kepuasan Kerja berpengaruh signifikan terhadap Organizational Citizenship Behavior, Kecerdasan Emosional berpengaruh signifikan terhadap OCB, Motivasi Kerja berpengaruh signifikan terhadap OCB, Kepuasan Kerja memediasi Kecerdasan Emosional terhadap OCB, Kepuasan Kerja memediasi Motivasi Kerja terhadap OCB. Hasil Uji F menunjukkan nilai F sebesar 125,764 dengan nilai signifikansi $0,000<0,05$ dengan kesimpulan variabel Kecerdasan Emosional, Motivasi Kerja dan Kepuasan Kerja berpengaruh signifikan terhadap Organizational Citizenship Behavior (OCB). Koefisien determinasi $\left(\mathrm{R}^{2}\right)$ total sebesar 0,798 dapat diartikan variasi OCB Karyawan di PT.Pos Indonesia Persero Surakarta dijelaskan oleh variabel Kecerdasan Emosional, Motivasi Kerja dan Kepuasan Kerja sebesar 79,8\% dan sisanya $20,2 \%$ dijelaskan oleh variabel-variabel lain di luar variabel-variabel yang diteliti dalam penelitian ini.

Kata Kunci : Kecerdasan Emosional, Motivasi Kerja, Kepuasan Kerja, Organizational Citizenship Behavior
\end{abstract}

\begin{abstract}
The purpose of this study was to analyze the Influence Emotional Intelligent and Work Motivation on Organizational Citizenship Behavior (OCB) with Job Satisfaction as a Mediating variable (Study at employees PT. Pos Indonesia Persero Surakarta). This study used 168 employees of PT. Pos Indonesia Persero Surakarta. The sampling technique was done by using probability sampling. In this study a model of analysis was Regression Analysis with path analysis. Hypothesis Test Results show Emotional Intelligence has a significant effect on Job Satisfaction, Work Motivation has a significant effect on Job Satisfaction, Job Satisfaction has a significant effect on Organizational Citizenship Behavior, Emotional Intelligence has a significant effect on OCB, Work Motivation has a significant on OCB, Job Satisfaction mediates Emotional Intelligence towards OCB, Job Satisfaction mediates Work Motivation towards Organizational Citizenship Behavior (OCB). F test results are known the value of $F=125,764$ significance of $0.000<0.05$, with the conclusion of the variables Emotional Intelligence, Work Motivation and Job Satisfaction have a significant effect on Organizational Citizenship Behavior (OCB). The total coefficient of determination (R2) of 0.798 can be interpreted as variation in OCB Employees at PT. Pos Indonesia Persero Surakarta explained by the variables Emotional Intelligence, Work Motivation and Job Satisfaction of $79.8 \%$ and the remaining $20.2 \%$ is explained by other variables outside the variables studied in this study.
\end{abstract}

Keyword: Emotional Intelligent, Work Motivation, Job Satisfaction, and Organizational Citizenship Behavior.

\section{PENDAHULUAN}

Setiap perusahaan mempunyai berbagai tujuan yang berbeda yang dalam pelaksanaannya di kelola karyawan. Oleh sebab itu karyawan merupakan faktor utama dalam semua kegiatan perusahaan guna mencapai tujuan perusahaan secara optimal. Setiap karyawan dalam suatu perusahaan berusaha untuk mencapai hasil kerja yang optimal sehingga akan memberikan 
kontribusi yang positif bagi keberhasilan perusahaan. Agar dapat mencapai hasil tersebut perlu adanya kepuasan kerja yang tinggi untuk diberikan kepada karyawan sehingga karyawan tidak hanya bekerja sesuai dengan deskripsi pekerjaan saja namun juga melakukan kegiatankegiatan di luar deskripsi pekerjaan (Extra-role) karyawan yang demikian disebut juga dengan Organizational Citizenship Behavior (OCB).

Organizational Citizenship Behavior (OCB) merupakan salah satu perilaku sukarela yang tampak dan dapat diamati. Perilaku OCB cenderung melihat seorang karyawan sebagai makhluk sosial (menjadi anggota organisasi), sebagai makhluk sosial mempunyai kemampuan untuk memiliki empati kepada orang lain dan lingkunganya, perilaku sosial oleh karyawan muncul karena perasaan sebagai anggota organisasi dan merasa mendapat kepuasan kerja apabila dapat melakukan sesuatu yang lebih kepada organisasi. Goleman (2005) menjelaskan dalam hal bekerja setiap individu mempunyai perilaku-perilaku yang berbeda, hal ini disebabkan adanya rangsangan-rangsangan tertentu yang menyebabkan individu tersebut melakukan suatu tindakan yang dapat ditentukan oleh emotional intelligence (kecerdasan emosi).

Kecerdasan emosional dapat membantu seorang karyawan dalam melaksanakan atau menjalankan pekerjaannya, selain itu dapat pula memotivasi para karyawan melakukan perilaku positif yang ekstra secara tulus dan membantu membangun relasi sosial dalam lingkungan keluarga, lingkungan kerja atau kantor, maupun lingkungan sosial masyarakat. Membicarakan kepuasan kerja juga tidak terlepas dari motivasi kerja karyawan, bila karyawan termotivasi maka dapat bekerja dengan lebih optimal. Demikian juga yang terjadi di PT. Pos Indonesia Persero Surakarta sebagai salah satu perusahaan yang bergerak di bidang jasa pelayanan dan pengiriman sangatlah di butuhkan partisipasi aktif dan kerjasama antar rekan kerja. Mengetahui pentingnya OCB para karyawan bagi kemajuan dan keberlangsungan perusahaan, maka OCB perlu dimunculkan dan di tingkatkan. Permasalahan yang muncul dalam perusahaan adalah kurangnya Organizational Citizenship Behavior pada karyawan PT. Pos Indonesia Persero Surakarta. Hal ini dapat menjadi fokus perusahaan untuk menemukan penyebab fenomena tersebut sebagai salah satu cara untuk menyelesaikan masalah.

Dalam penelitian ini, ingin mengkaji dan menganalisis pengaruh pengaruh kecerdasan emosional dan motivasi kerja terhadap
Organizational Citizenship Behavior (OCB) dengan kepuasan kerja sebagai varibel mediasi.

\section{KECERDASAN EMOSIONAL}

Cooper dan Sawaf (1999) mendefinisikan bahwa kecerdasan emosional adalah kemampuan merasakan, memahami, dan secara selektif menerapkan daya dan kepekaan emosi sebagai sumber energi dan pengaruh yang manusiawi. Salovey dan Mayer dalam Goleman (2005) menjelaskan bahwa kecerdasan emosional merupakan kemampuan untuk mengenali perasaan, meraih dan membangkitkan perasaan untuk membantu pikiran, memahami perasaan dan maknanya serta mengendalikan perasaan secara mendalam sehingga membantu perkembangan emosi dan intelektual.

\section{- Indikator Kecerdasan Emosional}

1) Kesadaran diri (self-awareness) merupakan kemampuan untuk mengetahui apa yang kita rasakan pada suatu saat, dan menggunakannya untuk memadu pengambilan keputusan diri sendiri, serta tolok ukur yang realistis atas kemampuan diri dan kepercayaan diri yang kuat.

2) Pengaturan diri (self-regulation) merupakan kemampuan untuk menangani emosi diri sendiri sehingga berdampak positif kepada pelaksanaan tugas, peka terhadap kata hati dan sanggup menunda kenikmatan sebelum tercapainya suatu sasaran, serta mampu pulih dari tekanan emosi.

3) Motivasi diri sendiri (self-motivation) merupakan kemampuan untuk menggunakan hasrat diri yang paling dalam untuk menggerakkan dan menuntun menuju sasaran, membantu mengambil inisiatif dan bertindak sangat efektif, dan untuk bertahan menghadapi kegagalan dan frustasi.

4) Empati (emphaty) merupakan kemampuan untuk merasakan yang dirasakan oleh orang lain, mampu memahami prespektifmereka, menumbuhkan hubungan saling percaya dan menyelaraskan diri dengan berbagai tipe orang.

5) Ketrampilan sosial (Interpersonal Skill) merupakan kemampuan untuk menangani emosi dengan baik ketika berhubungan dengan orang lain dan dengan cermat membaca situasi dan jaringan sosial, berinteraksi dengan lancar, menggunakan ketrampilan ini untuk mempengaruhi dan memimpin, bermusyawarah dan menyelesaikan perselisihan, serta untuk bekerja sama dalam tim. 


\section{MOTIVASI KERJA}

Motivasi adalah pemberian daya gerak yang menciptakan kegairahan kerja seseorang, agar mereka mau bekerjasama, bekerja efektif dan terintegrasi dengan segala daya upaya untuk mencapai kepuasan. (Hasibuan, 2009). Siagian Sondang P (2002), menyatakan bahwa motivasi merupakan daya dorong bagi seseorang untuk memberikan kontribusi yang sebesar mungkin demi keberhasilan organisasi mencapai tujuannya.

\section{- Teori Motivasi}

Menurut Hariandja (2002), teori motivasi dikelompokkan menjadi dua kategori umum antara lain :

1. Motivasi sebagai dorongan internal (Internal Theory / Content Theory). Teori motivasi yang termasuk kategori ini antara lain :

a) Teori Hirarki Kebutuhan (Need Hierarchy) dari A. Maslow.

Menurut teori ini kebutuhan dan kepuasan seseorang identik dengan kebutuhan biologis dan psikologis, yaitu berupa material dan non material. Dasar teori ini adalah bahwa manusia merupakan makhluk yang keinginannya tak terbatas atau tanpa henti, alat motivasinya adalah kepuasan yang belum terpenuhi serta kebutuhannya berjenjang. Jenjang tersebut dari rendah sampai yang paling tinggi adalah kebutuhan fisiologis, rasa aman, sosialisasi, penghargaan dan aktualisasi diri.

b) Teory $\mathrm{X}$ dan $\mathrm{Y}$

Teori $\mathrm{X}$ mengasumsikan bahwa karyawan rata-rata malas bekerja, karyawan tidak berambisi untuk mencapai prestasi optimal dan selalu menghindarkan tanggungjawab, karyawan lebih suka dibimbing, diperintah dan diawasi, karyawan lebih mementingkan dirinya sendiri.

Teori Y mengasumsikan bahwa karyawan rata-rata rajin bekerja, berambisi untuk maju dalam mencapai prestasi dan karyawan berusaha untuk mencapai sasaran organisasi.

c) Teori Motivasi Prestasi (Achievement Motivation) dari Mc. Clelland.

Teori ini menyatakan bahwa seseorang pekerja memiliki energi potensial yang dapat dimanfaatkan tergantung pada dorongan motivasi, situasi, dan peluang yang ada. Kebutuhan karyawan yang dapat memotivasi gairah kerja adalah kebutuhan akan prestasi (need for achievement), kebutuhan untuk berkuasa (Need of power) yaitu kebutuhan untuk lebih kuat, lebih berpengaruh terhadap orang lain, dan kebutuhan afiliasi (need for affiliation), yaitu kebutuhan untuk disukai, mengembangkan, atau memelihara persahabatan dengan orang lain. (Hasibuan, 2009).

d) Teori ERG (Existance, Relatedness, and Growth) dari alderfer.

Teori ini mengemukkan bahwa ada tiga kelompok kebutuhan yang utama, yaitu : kebutuhan akan keberadaan (existence) berhubungan dengan kebutuhan untuk mempertahankan keberadaan seseorang dalam hidupnya, kebutuhan akan afiliasi (relatedness) berhubungan dengan kebutuhan untuk berinteraksi dengan orang lain, kebutuhan akan kemajuan (growth), berhubungan dengan pengembangan diri. (Hasibuan, 2009).

e) Teori Dua Faktor dari Frederick Herzberg.

Menurut teori ini dalam melaksanakan pekerjaannya dipengaruhi oleh dua faktor utama yang merupakan kebutuhan yaitu: Faktor pemeliharaan. Merupakan faktor-faktor yang berhubungan dengan hakekat pekerja yang ingin memperoleh ketentraman badaniah. Faktor motivasi, merupakan motivasi yang menyangkut kebutuhan psikologis yang berhubungan dengan penghargaan terhadap pribadi yang secara langsung berkaitan dengan pekerjaan. (Hasibuan, 2009)

2. Motivasi sebagai dorongan eksternal atau teori keadilan, antara lain :

a) Teori Keadilan

Teori ini menyatakan bahwa keadilan merupakan daya penggerak yang memotivasi semangat kerja seseorang, jadi atasan harus bertindak adil terhadap semua bawahannya secara obyektif. Jika prinsip ini diterapkan dengan baik maka semangat kerja karyawan cenderung akan meningkat. (Hasibuan, 2009).

b) Teori Harapan 
Teori ini dikemukakan oleh Victor $\mathrm{H}$. Vroom yang menyatakan bahwa kekuatan yang memotivasi seseorang untuk bekerja tergantung dari hubungan timbal balik antara apa yang diinginkan dari hasil pekerjaannya. (Hasibuan, 2009).

\section{KEPUASAN KERJA}

Kepuasan kerja merupakan keadaan emosional yang menyenangkan atau tidak menyenangkan dimana para karyawan memandang pekerjaan mereka. Kepuasan kerja mencerminkan perasaan seseorang terhadap pekerjaannya. Kepuasan kerja ini nampak dalam sikap positif karyawan terhadap pekerjaan dan segala sesuatu yang dihadapi di lingkungankerjanya (Handoko, 1998).

\section{- Faktor-faktor yang Mempengaruhi} Kepuasan Kerja

Ada 5 faktor penentu kepuasan kerja yang disebut dengan Job Descriptive Index (JDI) (Luthans dan Spector dalam Robbins, 2008), yaitu : Pekerjaan itu sendiri, Gaji, Kesempatan atau Promosi, Supervisor, Rekan Kerja.

- Teori Kepuasan Kerja

1) Teori Dua Faktor Herzberg (Herzberg Two Factor Theory)

2) Teori Faset (Facet Theory)

3) Teori Proses Informasi Sosial (The Social Information Process Theory)

4) Teori Proses Berlawanan dari Landy (Landy's Opponent Process Theory)

\section{- Pengukuran Kepuasan Kerja}

Beberapa instrumen yang dapat digunakan sebagai pengukuran kepuasan kerja secara umum menggunakan instrumen kuesioner. Tiga instrumen kepuasan kerja yang sering dipakai antara lain : The Minnesota Satisfaction Questionnaire (MSQ), Job Disciptive Index (JDI), dan The Job Diagnostic Survey (JDS).

\section{ORGANIZATIONAL BEHAVIOR (OCB)}

Organ et al., (2006) mengungkapkan "organizational citizenship behavior (OCB) seringkali didefinisikan sebagai perilaku individu yang mempunyai kebebasan untuk memilih secara tidak langsung atau secara eksplisit diakui oleh sistem reward, dan memberi kontribusi pada keefektifan fungsi organisasi”. Selain itu Organ et al., (2006) mengatakan bahwa OCB sebagai "perilaku dan sikap yang menguntungkan organisasi yang tidak bisa di tumbuhkan dengan basis kewajiban peran formal maupun dengan bentuk kontrak atau rekompensasi". Contohnya meliputi bantuan pada teman kerja untuk meringankan beban kerja mereka, tidak banyak beristirahat, melaksanakan tugas yang tidak diminta, dan membantu orang lain untuk menyelesaikan masalah.

\section{- Dimensi-dimensi Organizational Citizenship Behavior (OCB)}

Organ, 1988; dalam Podsakoff, 2000 mengidentifikasikan 5 dimensi tentang OCB, yaitu: Altruism, Courtesy, Sportmanship, Conscientiousness, Civic Virtue.

\section{- Motif-motif yang Mendasari OCB}

Seperti halnya sebagian besar perilaku yang lain, OCB didorong atau dimotivasi oleh banyak hal. Menurut McClelland, manusia memiliki tiga motif yaitu :

1) Motif berprestasi (nAch), mendorong orang untuk menunjukkan suatu standart keistimewaan (excellence), mencari prestasi, dorongan untuk unggul mencapai sederetan standar guna meraih kesuksesan.

2) Motif akan Afiliasi (nAff), mendorong individu untuk mewujudkan, memelihara hubungan dengan orang lain, adanya hasrat akan hubungan persahabatan dan kedekatan personal.

3) Motif kekuasaan (nPow), mendorong orang untuk mencari status dan situasi dimana mereka dapat mengontrol pekerjaan atau tindakan orang lain, kebutuhan untuk membuat orang lain berperilaku dengan cara yang diinginkan.

\section{- Manfaat OCB Bagi Perusahaan}

Manfaat OCB diadaptasi dari penelitian Podsakoff dan Mackenzie (2000) dapat disimpulkan sebagai berikut:

1. OCB dapat meningkatkan produktivitas Kerja.

2. OCB dapat meningkatkan produktivitas Pimpinan.

3. OCB menghemat sumber daya yang dimiliki manajemen dan organisasi/ lembaga secara keseluruhan. 
4. OCB membantu menghemat energi sumber daya yang langka untuk memelihara fungsi kelompok.

5. OCB dapat menjadi sarana efektif untuk mengkooordinasikan kegiatan-kegiatan kelompok kerja.

6. OCB meningkatkan kemampuan organisasi untuk menarik dan mempertahankan pegawai terbaik.

7. OCB meningkatkan stabilitas organisasi kinerja organisasi.

8. OCB meningkatkan kemampuan organisasi untuk beradaptasi dengan perubahan lingkungan.

\section{METODE}

\section{Partisipan}

Penelitian ini dilakukan di PT. Pos Indonesia (Persero) Surakarta, yang beralamat di Jl. Jendral Sudirman No.8 Solo 57111. Penelitian ini merupakan penelitian assosiatif (hubungan) yaitu penelitian yang bertujuan untuk mengetahui hubungan dua variabel atau lebih. Populasi dalam penelitian ini adalah semua karyawan PT. Pos Indonesia (Persero) Surakarta. Metode pengambilan sampel yang digunakan adalah metode probability sampling yaitu dimana setiap anggota populasi mempunyai peluang yang sama untuk dipilih menjadi anggota sampel, dengan jumlah sampel sebanyak 168 orang.

\section{Pengukuran}

Penelitian ini menggunakan skala Likert dengan 5 alternatif pilihan jawaban yaitu $1=$ Sangat Tidak Setuju (STS), 2= Tidak Setuju (S), 3= Netral (N), 4= Setuju (S) dan 5= Sangat Setuju (SS).

- Variabel Kecerdasan Emosional (X1) menggunakan aspek-aspek dari Goleman (2005) yaitu : (a) kesadaran diri( self awarness), (b) pengendalian diri (self control), (c) motivasi (motivation), (d) empati (empathy), (e) ketrampilan sosial (social skills), Diukur menggunakan 14 item pernyataan.

- Varibel Motivasi Kerja (X2) menggunakan Aspek-aspek berdasarkan teori dari Mc. Clelland yaitu : Kebutuhan akan prestasi (need for achievement), kebutuhan afiliasi (need affiliation), dan kebutuhan untuk berkuasa (need of power). Diukur dengan 11 item pernyataan.

- Variabel Kepuasan Kerja (X3) menggunakan aspek-aspek sesuai dengan pendapat Luthans (2006), yaitu pekerjaan itu sendiri, kepuasan terhadap gaji, kepuasan terhadap kesempatan promosi pekerjaan, kepuasan terhadap atasan dan kepuasan terhadap rekan kerja. Semakin tinggi skor yang diperoleh maka semakin tinggi kepuasan kerjanya. Pengukuran variabel kepuasan kerja dengan menggunakan Job Descriptive Index (JDI) yang diperkenalkan oleh Smith, Kendal, dan Hulin pada tahun 1969. Diukur dengan 8 item pernyataan.

- Variabel Organizational Citizenship Behavior (X4), di susun berdasarkan lima dimensi menurut Organ 1988 yang di kembangkan Podsakoff (2000) yaitu altruism, courtesy, sportmanship, conscientiousness, dan civic virtue. Diukur dengan 13 item pernyataan.

\section{Hipotesis}

$\mathrm{H}_{1} \quad$ : Kecerdasan Emosional berpengaruh signifikan terhadap Kepuasan kerja.

$\mathrm{H}_{2}$ : Motivasi Kerja berpengaruh signifikan terhadap Kepuasan Kerja.

$\mathrm{H}_{3}$ : Kepuasan Kerja berpengaruh signifikan terhadap Organizational Citizenship Behavior (OCB).

$\mathrm{H}_{4}$ : Kecerdasan Emosional berpengaruh signifikan terhadap Organizational Citizenship Behavior (OCB).

$\mathrm{H}_{5}$ : Motivasi Kerja berpengaruh signifikan terhadap Organizational Citizenship Behavior (OCB).

$\mathrm{H}_{6}$ : Kepuasan Kerja memediasi Kecerdasan emosional terhadap Organizational Citizenship Behavior (OCB).

$\mathrm{H}_{7}$ : Kepuasan Kerja memediasi Motivasi Kerja terhadap Organizational Citizenship Behavior (OCB).

\section{Model Analisis}

Dalam penelitian ini untuk Uji Instrumen Penelitian menggunakan Uji Validitas dan Uji Reliabilitas.. Uji Asuksi Klasik terdapat beberapa pengujian yang harus dilakukan terlebih dahulu sebelum melakukan pengujian hipotesis yakni Uji Multikolonieritas, Uji Autokorelasi, Uji Heteroskendastisitas, dan Uji Normalitas.

Model analisis yang digunakan adalah Analisis Regresi Linier Berganda dengan Moderated Regresion Analysis (MRA). Uji Hipotesis menggunakan Analisis Jalur (Path Analysis) , Uji t, Uji F dan Koefisien Determinasi $\left(\mathrm{R}^{2}\right)$.

HASIL DAN PEMBAHASAN Uji Validitas dan Reliabilitas 
Hasil pengujian Validitas indikator dari semua variabel bebas maupun varibel terikat menunjukkan valis, karena nilai sig $<0,05$ sehingga dinyatakan bahwa semua variabel penelitian telah valid. Hasil pengujian Reliabilitas menunjukkan semua variabel dinyatakan Reliabel dengan nilai Cronbach's Alpha $>0,60$.

\section{Uji Asumsi Klasik}

- Uji Normalitas

Tabel 1. Hasil Uji Normalitas

\begin{tabular}{|c|c|c|}
\hline & & $\begin{array}{l}\text { Unstandardiz } \\
\text { ed Residual }\end{array}$ \\
\hline $\bar{N}$ & & 168 \\
\hline \multirow[t]{2}{*}{ Normal Parameters ${ }^{a, b}$} & Mean &, 0000000 \\
\hline & Std. Deviation & 2,88841729 \\
\hline Most Extreme & Absolute & , 112 \\
\hline \multirow[t]{2}{*}{ Differences } & Positive & ,112 \\
\hline & Negative &,- 074 \\
\hline Kolmogorov-Smirnov Z & & 1,450 \\
\hline Asymp. Sig. (2-tailed) & & 230 \\
\hline
\end{tabular}

Berdasarkan uji statistik normalitas dengan Kolmogorov- Smirnov Test diperoleh nilai KSZ 1,450 dan Asymp. Sig sebesar 0,230 lebih besar dari 0,05 maka dapat disimpulkan data berdistribusi normal.

- Uji Multikolinieritas

Tabel 2. Collinearity statistic

\begin{tabular}{|c|c|c|}
\hline \multirow{2}{*}{ Model } & \multicolumn{2}{|c|}{ Collinearity Statistic } \\
\hline & Tolerance & VIF \\
\hline $\begin{array}{l}\text { Kecerdasan } \\
\text { (X1) }\end{array}$ & 0,197 & 5,073 \\
\hline Motivasi Kerja (X2) & 0,486 & 2,059 \\
\hline Kepuasan Kerja (X3) & 0,262 & 3,816 \\
\hline
\end{tabular}

Berdasarkan tabel diatas tidak terjadi multikolinearitas, dari hasil koefisien regresi didapatkan bahwa nilai tolerance lebih dari 0,1 dan nilai VIF nya kurang dari 10 . Oleh karena itu data yang digunakan dalam penelitian ini tidak ada multikolinearitas antara variabel bebas dalam regresi.

\section{- Uji Heteroskedastisitas}

Tabel 3. Uji Heteroskedastisitas

\begin{tabular}{|c|c|c|c|c|c|c|}
\hline \\
\hline \multirow[b]{2}{*}{ Model } & & \multicolumn{2}{|c|}{$\begin{array}{c}\text { Unstandardized } \\
\text { Coefficients }\end{array}$} & \multirow{2}{*}{$\begin{array}{c}\begin{array}{c}\text { Standardized } \\
\text { Coefficients } \\
\text { Beta }\end{array} \\
\end{array}$} & \multirow[b]{2}{*}{$\mathrm{t}$} & \multirow[b]{2}{*}{ Sig. } \\
\hline & & B & Std. Error & & & \\
\hline \multirow[t]{4}{*}{1} & (Constant) & 6,056 & 1,475 & & 4,106 &, 000 \\
\hline & Kecerdasan Emosional & -041 & .042 & -162 &,- 958 & .339 \\
\hline & Motivasi Kerja & $-0,039$ & ,046 & -158 &,- 961 & .314 \\
\hline & Kepuasan Kerja & .185 & .058 & .190 & 1,976 & .350 \\
\hline
\end{tabular}

Berdasarkan Uji Heteroskedastisitas pada tabel 3 dapat disimpulkan bahwa tidak terdapat heteroskedastisitas pada persamaan regresi tersebut, Hal tersebut terlihat dari tidak adanya variabel bebas yang memiliki signifikansi dibawah 0,05. Dengan demikian dapat disimpulkan bahwa persamaan regresi dengan menggunkan Uji Park tidak mempunyai masalah heteroskedastisitas.

\section{- Uji Autokorelasi}

Berdasarkan hasil pengujian dengan menggunakan uji Durbin - Watson atas residual persamaan regresi diperoleh angka dhitung sebesar 2,387 sehingga tidak terjadi autocorelation.

\section{Hasil Regresi Linier Berganda}

a. Hasil Analisis Persamaan I

Tabel 4. Hasil Analisis Jalur Persamaan I

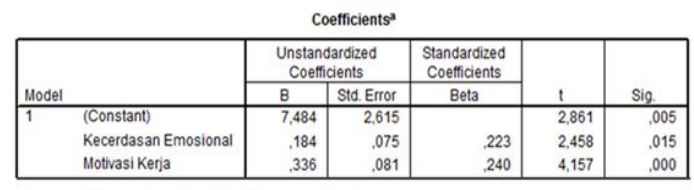

a. Dependent Variable: Kepuasan Kerja

Persamaan Regresi yang diperoleh dari perhitungan tersebut adalah sebagai berikut :

$$
\mathrm{Y}_{1}=7.484+0,223 \cdot \mathrm{X}_{1}+0,240 \cdot \mathrm{X}_{2+}
$$
$\mathrm{e}_{1}$

Dari hasil di atas maka dapat dijelaskan sebagai berikut: 
1) $\beta_{1}=$ Koefisien regresi variabel Kecerdasan Emosional sebesar 0,223 hal ini menunjukkan bahwa variabel Kecerdasan Emosional berpengaruh positif terhadap Kepuasan Kerja pada Karyawan PT. Pos Indonesia Persero Surakarta, hal ini berarti bahwa karyawan yang mempunyai kecerdasan emosional yang tinggi cenderung memiliki Kepuasan Kerja yang tinggi.

2) $\beta_{2}=$ Koefisien regresi variabel Motivasi Kerja sebesar 0,240 hal ini menunjukkan bahwa variabel Motivasi Kerja berpengaruh positif terhadap Kepuasan Kerja pada Karyawan PT. Pos Indonesia Persero Surakarta, hal ini berarti bahwa apabila motivasi kerja karyawan ditingkatkan, maka Kepuasan Kerja akan meningkat.

b. Hasil Analisis Persamaan II Uji Moderasi Tabel. 5 Hasil Uji Regresi Moderasi

Coefficients $^{3}$

\begin{tabular}{|c|c|c|c|c|c|c|}
\hline \multirow[b]{2}{*}{ Model } & & \multicolumn{2}{|c|}{$\begin{array}{l}\text { Unstandardized } \\
\text { Coefficients }\end{array}$} & \multirow{2}{*}{$\begin{array}{c}\begin{array}{c}\text { Standardized } \\
\text { Coefficients }\end{array} \\
\text { Beta } \\
\end{array}$} & \multirow[b]{2}{*}{$t$} & \multirow[b]{2}{*}{ Sig. } \\
\hline & & $B$ & Std. Error & & & \\
\hline \multirow[t]{5}{*}{1} & (Constant) & 35,990 & 4,763 & & 7,557 & .000 \\
\hline & Kecerdasan Emosional & 1,599 & .433 & 1,935 & 3,691 & .000 \\
\hline & Motivasi Kerja & $-2,184$ & .650 & $-1,560$ & $-3,359$ & .001 \\
\hline & Moderat 1 & -040 & .013 & $-3,098$ & $-3,183$ & .002 \\
\hline & Moderat2 & .068 & .017 & 3,358 & 3,968 & .000 \\
\hline
\end{tabular}

a. Dependent Variable: $\mathrm{OCB}$

Persamaan Regresi Kedua

$$
\begin{aligned}
\mathrm{Y}_{2}= & 1,935 \mathrm{X} 1-1,560 \mathrm{X} 2-3,098 \mathrm{X} 1 . \mathrm{X} 3- \\
& 3,358 \mathrm{X} 2 \cdot \mathrm{X} 3+\mathrm{e} 2
\end{aligned}
$$

Dari hasil diatas maka dapat dijelaskan sebagai berikut:

1) $\beta_{1}=$ Koefisien regresi variabel Keceerdasan Emosional sebesar 1,935 hal ini menunjukkan bahwa variabel Kecerdasan Emosional berpengaruh positif terhadap Organizational Citizenship Behavior (OCB) pada Karyawan PT. Pos Indonesia Persero Surakarta, hal ini mengindikasikan bahwa karyawan dengan kecerdasan emosional yang tinggi cenderung meningkatkan perilaku Organizational Citizenship Behavior (OCB).

2) $\beta_{2}=$ Koefisien regresi variabel Motivasi Kerja sebesar - 1,560 hal ini menunjukkan bahwa variabel Motivasi kerja berpengaruh negatif terhadap Organizational Citizenship Behavior (OCB), hal ini mengindikasikan bahwa apabila motivasi kerja karyawan rendah maka akan berdampak pada penurunan perilaku
Organizational Citizenship Behavior (OCB) pada karyawan PT. Pos Indonesia Persero Surakarta.

3) $\beta 3=$ Koefisien regresi kepuasan Kerja sebesar - 3,098 hal ini menunjukkan bahwa variabel kepuasan kerja berpengaruh negatif terhadap Organizational Citizenship Behavior (OCB), hal ini mengindikasikan bahwa apabila

\begin{tabular}{|c|c|c|c|c|c|}
\hline \multicolumn{6}{|c|}{ Coefficients $^{\mathrm{a}}$} \\
\hline \multirow[b]{2}{*}{ Model } & \multicolumn{2}{|c|}{$\begin{array}{c}\text { Unstandardized } \\
\text { Coefficients }\end{array}$} & \multirow{2}{*}{$\begin{array}{c}\begin{array}{l}\text { Standardized } \\
\text { Coefficients }\end{array} \\
\text { Beta } \\
\end{array}$} & \multirow[b]{2}{*}{$t$} & \multirow[b]{2}{*}{ Sig. } \\
\hline & $B$ & Std.Error & & & \\
\hline (Constant) & 35,990 & 4,763 & & 7,557 &, 000 \\
\hline Kecerdasan Emosional & 1,599 & .433 & 1,935 & 3,691 & .000 \\
\hline Motivasi Kerja & $-2,184$ &, 650 & $-1,560$ & $-3,359$ &, 001 \\
\hline Kepuasan Kerja & 1,486 & .479 & $-1,725$ & $-3,156$ & .002 \\
\hline Moderat 1 &,- 040 & 013 & $-3,098$ & $-3,183$ &, 002 \\
\hline Moderat 2 & ,068 &, 017 & 3,358 & 3,968 &, 000 \\
\hline
\end{tabular}
kepuasan kerja karyawan rendah maka akan

berdampak pada penurunan perilaku Organizational Citizenship Behavior (OCB) pada karyawan PT. Pos Indonesia Persero Surakarta.

4) $\beta_{4}=$ Koefisien regresi variabel Kepuasan Kerja berpengaruh negatif antara Kecerdasan Emosional terhadap Organizational Citizenship Behavior (OCB). Hal ini ditunjukkan dengan nilai koefisien moderat 1 sebesar - 3,098. Hal ini mengindikasikan bahwa kepuasan kerja kerja tidak berhasil memoderasi antara kecerdasan emosional terhadap Organizational Citizenship Behavior (OCB) pada karyawan PT. Pos Indonesia Persero Surakarta.

5) $\beta_{5}=$ Koefisien regresi variabel Kepuasan Kerja berpengaruh positif antara Motivasi Kerja terhadap Organizational Citizenship Behavior (OCB). Hal ini ditunjukkan dengan

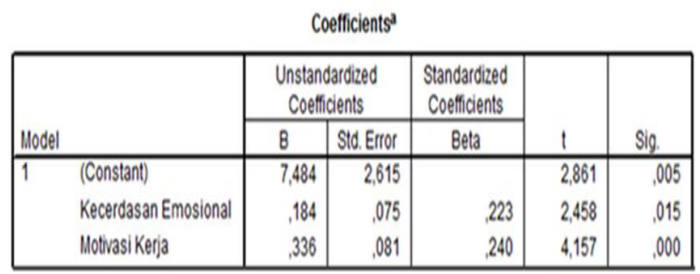

a. Dependent Variable: Kepuasan Kerja

nilai koefisien moderat 2 sebesar 3,358. Hal ini mengindikasikan bahwa Kepuasan Kerja berhasil memoderasi antara Motivasi kerja terhadap Organizational Citizenship Behavior (OCB) pada karyawan PT. Pos Indonesia Persero Surakarta. 


\section{Uji Hipotesis}

\section{a. Uji t Persamaan I}

Tabel 6.Uji t Persamaan I

1) Kecerdasan emosional berpengaruh signifikan terhadap Kepuasan Kerja Karyawan PT. Pos Indonesia Persero Surakarta. Dapat dilihat pada tabel 6 nilai signifikansinya $0,015<$ 0,05 , maka hasil analisis tersebut signifikan.

2) Motivasi kerja berpengaruh signifikan terhadap Kepuasan Kerja Karyawan pada Karyawan PT. Pos Indonesia Persero Surakarta. Dapat dilihat pada tabel 6 nilai sigifikansinya $0,000<0,05$, maka hasil analisis tersebut signifikan.

\section{b. Uji t Persamaan II}

Tabel 7. Uji t Persamaan II

1) Kecerdasan Emosional berpengaruh signifikan terhadap Organizational Citizenship Behavior (OCB) pada Karyawan PT. Pos Indonesia Persero Surakarta. Pada tabel 7 nilai signifikansinya sebesar $0,000<$ 0,05 sehingga hasil analisis tersebut signifikan.

2) Motivasi Kerja signifikan terhadap Organizational Citizenship Behavior (OCB) pada Karyawan PT. Pos Indonesia Persero Surakarta. Pada tabel 7 nilai signifikansinya sebesar $0,001<0,05$ sehingga hasil analisis tersebut signifikan.

3) Kepuasan Kerja signifikan terhadap Organizational Citizenship Behavior (OCB) pada Karyawan PT. Pos Indonesia Persero Surakarta. Pada tabel 7 nilai signifikansinya sebesar $0,002<0,05$, sehingga hasil analisis tersebut signifikan.

4) Kepuasan Kerja memediasi antara Kecerdasan Emosional terhadap Organizational Citizenship Behavior (OCB) pada Karyawan PT. Pos Indonesia Persero Surakarta. Pada tabel 7 nilai signifikansinya sebesar $0,002<0,05$, maka hasil analisis tersebut signifikan.

5) Kepuasan Kerja memediasi antara Motivasi Kerja terhadap Organizational Citizenship Behavior (OCB) pada Karyawan PT. Pos Indonesia Persero Surakarta. Pada tabel 7 nilai signifikansinya sebesar $0,000<0,05$, maka hasil analisis tersebut signifikan. c. Uji F

Tabel 8. Hasil Uji F

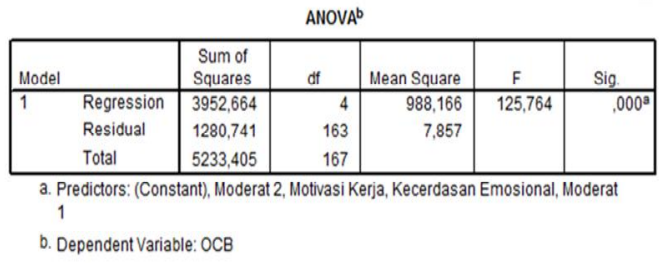

Hasil uji $\mathrm{F}$ diketahui besarnya nilai $\mathrm{F}=$ 125,764 signifikansi $0,000<0,05$. Sehingga dapat disimpulkan secara bersama-sama Kecerdasan Emosional, Motivasi Kerja dan Kepuasan Kerja berpengaruh signifikan terhadap Organizational Citizenship Behavior (OCB) karyawan PT. Pos Indonesia Persero Surakarta.

d. Koefisien determinasi $\left(\mathrm{R}^{2}\right)$

$$
\begin{aligned}
\mathrm{R}^{2} \text { total } & =1-\left\{\left(\epsilon_{1}\right)^{2} x\left(\epsilon_{2}\right)^{2}\right\} \\
& =1-\left\{(0,614)^{2} \times(0,702)^{2}\right\} \\
& =1-\{(0,411) \times(0,492)\} \\
& =1-0,202 \\
& =0,798
\end{aligned}
$$

Nilai $\mathrm{R}^{2}$ total sebesar 0,798 dapat diartikan variasi Organizational Citizenship Behavior (OCB) Karyawan di PT. Pos Indonesia Persero Surakarta dijelaskan oleh variabel Kecerdasan Emosional, Motivasi kerja dan Kepuasan kerja, sebesar $79,8 \%$ dan sisanya $20,2 \%$ dijelaskan variabel lain diluar model penelitian sebagai contoh Komitmen Organisasi dan Kinerja

\begin{tabular}{|c|c|c|c|}
\hline \multirow[b]{2}{*}{$\begin{array}{c}\text { Dari } \\
\text { Variabel }\end{array}$} & \multicolumn{2}{|c|}{ Koefisien Jalur } & \multirow[b]{2}{*}{ Total Pengaruh } \\
\hline & $\begin{array}{c}\text { DE } \\
\text { (Direct } \\
\text { Effect) }\end{array}$ & $\begin{array}{c}\mathrm{IE} \\
\text { (Indirect Effect) }\end{array}$ & \\
\hline $\mathrm{X}_{1}$ ke $\mathrm{X}_{3}$ & $P_{1}=0,223 * *$ & & $0,223 * *$ \\
\hline$X_{2}$ ke $X_{3}$ & $\mathrm{P}_{2}=0,240 * *$ & & $0,240 * *$ \\
\hline $\mathrm{X}_{1}$ ke $\mathrm{Y}$ & $\mathrm{P}_{4}=1,935^{* *}$ & & $1,935 * *$ \\
\hline $\mathrm{X}_{2}$ ke $\mathrm{Y}$ & $P_{5}=(-1,560)$ & & $-1,560$ \\
\hline $\mathrm{X}_{3}$ ke $\mathrm{Y}$ & $P_{3}=(-1,725)$ & & $-1,725$ \\
\hline $\begin{array}{c}\mathrm{X}_{1} \text { melalui } \mathrm{X}_{3} \\
\mathrm{Ke} \mathrm{Y}\end{array}$ & & $\begin{array}{l}=\mathrm{P}_{4} \times \mathrm{P}_{3} \\
=1,935 * * \times(-1,725) \\
=(-3,337)\end{array}$ & $\begin{array}{l}=\mathrm{P}_{4}+\left(\mathrm{P}_{4} \times \mathrm{P}_{3}\right) \\
=1,935^{* *}+(-1,725) \\
=0,210\end{array}$ \\
\hline $\begin{array}{c}\mathrm{X}_{2} \text { melalui }_{\mathrm{X}} \\
\text { Ke Y }\end{array}$ & & $\begin{array}{l}=\mathrm{P}_{5} \times \mathrm{P}_{3} \\
=(-1,560) \times(-1,725) \\
=2,691 * *\end{array}$ & $\begin{array}{l}=\mathrm{P}_{5}+\left(\mathrm{P}_{5} \times \mathrm{P}_{3}\right) \\
=(-1.560)+2,691 \\
=1,131 * *\end{array}$ \\
\hline
\end{tabular}
Karyawan.

\section{e. Efek Mediasi}

Tabel 9 Pengaruh Langsung, Pengaruh Tidak Langsung dan Total Pengaruh 
a) Pengaruh Langsung

1) Pengaruh Kecerdasan Emosional Terhadap Kepuasan Kerja. Berdasarkan Tabel 9 diketahui Kecerdasan Emosional berpengaruh signifikan terhadap Kepuasan Kerja, dengan nilai Koefisien sebesar 0,223.

2) Pengaruh Motivasi Kerja Terhadap Kepuasan Kerja. Berdasarkan Tabel 9 diketahui Motivasi Kerja berpengaruh signifikan terhadap Kepuasan Kerja, dengan nilai koefisien sebesar 0,240.

3) Pengaruh Kecerdasan Emosional terhadap Organizational Citizenship Behavior (OCB). Berdasarkan Tabel 9 diketahui Kecerdasan Emosional berpengaruh signifikan terhadap Organizational Citizenship Behavior (OCB), dengan nilai koefisien sebesar 1,935.

4) Pengaruh Motivasi Kerja Terhadap Organizational Citizenship Behavior (OCB). Berdasarkan Tabel 9 diketahui Motivasi Kerja berpengaruh tidak signifikan terhadap Organizational Citizenship Behavior (OCB), dengan nilai koefisien sebesar - 1,560.

5) Pengaruh Kepuasan Kerja Terhadap Organizational Citizenship Behavior (OCB). Berdasarkan Tabel 9 diketahui Kepuasan Kerja berpengaruh tidak signifikan terhadap Organizational Citizenship Behavior (OCB), dengan nilai koefisien sebesar -1,725.

\section{b) Pengaruh Tidak Langsung}

1) Berdasarkan tabel 9 diketahui pengaruh Kecerdasan Emosional signifikan terhadap Kepuasan Kerja dan Kepuasan Kerja berpengaruh tidak signifikan terhadap Organizational Citizenship Behavior (OCB) sebesar - 3,337.

2) Berdasarkan tabel 9 diketahui pengaruh Motivasi Kerja signifikan terhadap Kepuasan kerja dan Kepuasan Kerja Berpengaruh signifikan terhadap Organizational Citizenship Behavior (OCB) sebesar 2,691, maka kepuasan kerja memiliki peran sebagai intervening dengan model analisis mediation hubungan antara Motivasi kerja dan Organizational Citizenship Behavior (OCB).

\section{c) Pengaruh Total}

1) Pengaruh Total (Total Effect) variabel Kecerdasan Emosionl Terhadap Organizational Citizenship Behavior (OCB) melalui Kepuasan Kerja adalah 1,935 + ($1,725)=0,210$.
2) Pengaruh Total (Total Effect) variabel Motivasi Kerja Terhadap Organizational Citizenship Behavior (OCB) melalui Kepuasan Kerja sebesar $(-1,560)+2,691=$ 1,131

- Kesimpulam Analisis Jalur

Berdasarkan hasil analisis jalur langsung Kecerdasan Emosional terhadap Organizational Citizenship Behavior (OCB), merupakan jalur yang dominan dan efektif untuk meningkatkan perilaku Organizational Citizenship Behavior (OCB). Hubungan antar variabel dapat digambarkan sebagai berikut:

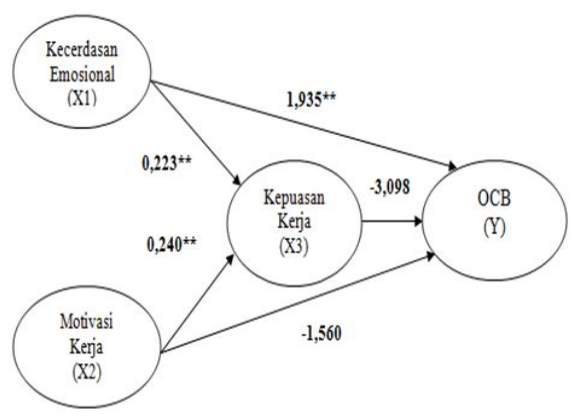

Gambar 1. Hasil Pengaruh Langsung, Tidak Langsung dan Pengaruh Total

\section{PEMBAHASAN}

\section{1) Hipotesis 1 "Kecerdasan Emosional berpengaruh signifikan terhadap Kepuasan kerja".}

Kecerdasan Emosional berpengaruh positif dan signifikan terhadap Kepuasan Kerja Karyawan PT. Pos Indonesia Persero Surakarta, hal ini ditunjukkan dengan nilai signifikan $95 \%(\alpha=0,05)$ atau dilihat dari nilai signifikansinya sebesar $0,015<0,05$, Hal ini berarti bahwa variabel kecerdasan emosional signifikan terhadap Kepuasan Kerja. Dengan kata lain Kecerdasan Emosional berpengaruh positif terhadap Kepuasan Kerja, maka $\mathbf{H}_{\mathbf{0}}$ ditolak dan $\mathbf{H}_{\mathbf{1}}$ diterima.

Kepuasan Kerja dipengaruhi oleh respon emosional terhadap suatu pekerjaan. Kecerdasan emosional berperan sebagai modal utama dalam pengendalian diri seseorang sehingga dapat menghasilkan kinerja yang baik (Patton, 1998). Kecerdasan emosional dapat membantu seorang karyawan 
dalam melaksanakan atau meningkatkan lingkungan kerja psikologis yang kondusif, serta dapat membantu karyawan dalam melaksanakan atau menjalankan pekerjaanya, selain itu dapat pula membantu membangun relasi sosial baik dalam lingkungan keluarga, lingkungan kerja maupun sosial masyarakat. Terciptanya relasi sosial tersebut dapat meningkatkan kepuasan dan produktivitas yang akan mewujudkan tujuan dan kesuksesan organisasi, sehingga dapat disimpulkan bahwa semakin tinggi kecerdasan emosional seseorang (karyawan) dalam mengelola emosi maka akan semakin tinggi pula kepuasan kerja yang dirasakan karyawan terhadap pekerjaannya. Hasil penelitian ini sejalan dengan penelitian yang dilakukan Wiwik Sumiyarsih dkk (2012).

2) Hipotesis 2 " Motivasi berpengaruh signifikan terhadap Kepuasan Kerja".

Motivasi kerja berpengaruh positif dan signifikan terhadap Kepuasan Kerja karyawan PT. Pos Indonesia Persero Surakarta, hal ini ditunjukkan dengan dengan taraf signifikan $95 \%(\alpha=0,05)$ atau dilihat dari nilai signifikansinya sebesar $0,000<$ 0,05 , Hal ini berarti bahwa variabel Motivasi kerja signifikan terhadap Kepuasan Kerja. Dengan kata lain Motivasi Kerja berpengaruh positif terhadap Kepuasan Kerja, maka $\mathbf{H}_{\mathbf{0}}$ ditolak dan $\mathrm{H}_{2}$ diterima.

Motivasi Kerja merupakan suatu proses yang merujuk kepada munculnya dorongan untuk melakukan aktivitas pekerjaan, sedagkan kepuasan kerja merujuk kepada perasaan positif karena terpenuhinya harapan atas aktivitas pekerjaan yang dilakukan. Saat individu termotivasi dan puas, maka individu akan berusaha untuk melakukan aktivitas pekerjaan yang ebih baik lagi, bahkan melakukan pekerjaan yang bukan menjadi pekerjaan utamanya.

Karyawan yang memiliki kepuasan kerja yang tinggi akan memiliki sikap tenang dalam bekerja, mempunyai motivasi bekerja yang tinggi dalam menghadapi pekerjaan yang banyak dan memiliki kondisi mental dan fisik yang menunjang dalam bekerja. Ia juga bekerja dengan tenang dan nyamanditempat kerja, dan mampu beradaptasi dengan lingkungan kerja serta mampu berkomunikasi dengan baik dengan rekan kerja dalam berbagai situasi. (Susatyo, 2013). Hasil penelitian ini sejalan dengan penelitian yang dilakukan oleh Susatyo Yumono dkk, (2014).
3) Hipotesis 3 “ Kepuasan Kerja berpengaruh signifikan terhadap Organizational Citizenship Behavior (OCB).

Kepuasan Kerja berpengaruh signifikan terhadap Organizational Citizenship Behavior (OCB) pada Karyawan PT. Pos Indonesia Persero Surakarta. Hal ini ditunjukkan dengan taraf signifikan 95\% $(\alpha=$ $0,05)$ atau dilihat dari nilai signifikansinya sebesar $0,002<0,05$, Hal ini berarti bahwa variabel Kepuasan Kerja signifikan terhadap Organizational Citizenship Behavior (OCB). Dengan kata lain Kepuasan Kerja berpengaruh positif terhadap OCB, maka $\mathbf{H}_{0}$ ditolak dan $\mathrm{H}_{3}$ diterima.

Dapat disimpulkan bahwa Setiap karyawan dalam suatu perusahaan berusaha untuk mencapai hasil kerja yang optimal sehingga akan memberikan kontribusi yang positif bagi keberhasilan perusahaan. Agar dapat mencapai hasil tersebut perlu adanya kepuasan kerja yang tinggi untuk diberikan kepada karyawan sehingga karyawan tidak hanya bekerja sesuai dengan deskripsi pekerjaan saja namun juga melakukan kegiatan0kegiatan di luar deskripsi pekerjaan (Extra-role) karyawan yang demikian disebut juga dengan Organizational Citizenship Behavior (OCB). Sehingga dapat disimpulkan bahwa semakin tinggi kepuasan kerja seseorang terhadap pekerjaannya, maka perilaku OCB juga akan semakin meningkat. Hasil penelitian ini sejalan dengan penelitian yang dilakukan oleh Farahiyah Eki Riantini \& Sandra Tahun 2016, dan Sustyo Yuwono dkk Tahun 2014.

\section{4) Hipotesis 4 " Kecerdasan Emosional berpengaruh signifikan terhadap Organizational Citizenship Behavior (OCB) ".}

Kecerdasan Emosional berpengaruh signifikan terhadap Organizational Citizenship Behavior (OCB) pada Karyawan PT. Pos Indonesia Persero Surakarta. Hal ini ditunjukkan dengan nilai taraf signifikan $95 \%$ $(\alpha=0,05)$ atau dilihat dari nilai signifikansinya sebesar $0,000<0,05$, Hal ini berarti bahwa variabel Kecerdasan Emosional berpengaruh signifikan terhadap Organizational Citizenship Behavior (OCB). Dengan kata lain Kecerdasan emosional berpengaruh positif terhadap Organizational Citizenship Behavior (OCB), maka $\mathbf{H}_{0}$ ditolak dan $\mathrm{H}_{4}$ diterima. 
Keterkaitan antara emosi dan perilaku seseorang menuntut kemampuan individu untuk dapat mengelola emosi dengan baik. Melalui kemampuan mengelola emosi, seorang (karyawan) akan merasakan dan memunculkan emosi positif dari dalam dirinya sehingga individu tersebut lebih peka dan mampu memahami atau berempati kepada orang lain maupun lingkungannya, serta bisa menyelaraskan nilai-nilai yang dianut lingkungannya, pada gilirannya hal tersebut akan membuat orang merasa lebih optimis tentang kemampuannya mencapai tujuan, meningkatkan kreativitas dan ketrampilan mengambil keputusan, serta membuat orang menjadi suka membantu (Goleman, 2007).

Dapat disimpulkan bahwa semakin tinggi kecerdasan emosional seseorang, yang di tunjukkan lewat kemampuan seseorang dalam mengelola emosi dan memahami orang lain, maka perilaku OCB yang di tunjukkan semakin tinggi pula. Hasil penelitian ini tidak sejalan dengan penelitian yang dilakukan oleh Wiwik Sumiyarsih dkk Tahun 2012.

5) Hipotesis 5 " Motivasi Kerja berpengaruh signifikan terhadap Organizational Citizenship Behavior (OCB).

$\begin{array}{ll}\text { Motivasi Kerja } & \text { berpengaruh } \\ \text { signifikan terhadap } & \text { Organizational }\end{array}$

Citizenship Behavior (OCB) pada Karyawan PT. Pos Indonesia Persero Surakarta. Hal ini ditunjukkan dengan nilai taraf signifikan $95 \%$ $(\alpha=0,05)$ atau dilihat dari nilai signifikansinya sebesar $0,001<0,05$, Hal ini berarti bahwa variabel Motivasi Kerja berpengaruh signifikan terhadap Organizational Citizenship Behavior (OCB). Dengan kata lain Motivasi Kerja berpengaruh positif terhadap Organizational Citizenship Behavior $(\mathrm{OCB})$, maka $\mathbf{H}_{0}$ ditolak dan $\mathbf{H}_{5}$ diterima.

Dapat disimpulkan bahwa peningkatan perilaku Organizational Citizenship Behavior (OCB) dapat dibentuk melalui adanya motivasi kerja yang tinggi oleh para pegawai. Dengan demikian jika karyawan PT.Indonesia Persero Surakarta ingin meningkatkan perilaku OCB karyawannya maka perlu memperhatikan tingkat motivasi yang dimiliki oleh karyawan dalam bekerja, motivasi dapat meningkatkan partisipasi karyawan, salah satunya ditunjukkan dengan perilaku karyawan yang bersedia melakukan peran diluar pekerjaan utamanya. Hasil penelitian ini sejalan dengan penelitian yang dilakukan oleh Sustyo Yuwono dkk Tahun 2014.

6) Hipotesis 6 "Kepuasan Kerja memediasi Kecerdasan Emosional terhadap Organizational Citizenship Behavior (OCB)".

Hasil pengaujian Hipotesis 1 menunjukkan bahwa Kecerdasan Emosional berpengaruh positif dan signifikan terhadap Kepuasan Kerja, hasil pengujian Hipotesis 4 juga menunjukkan bahwa Kecerdasan Emosional berpengaruh positif dan signifikan terhadap Organizational Citizenship Behavior (OCB). Hasil pengujian antar variabel bersifat positif dan signifikan sehingga terjadi mediasi, sehingga Hipotesis 6 diterima.

Dapat disimpulkan bahwa individu yang memiliki kecerdasan emosional akan mampu mengetahui kondisi emosionalnya dan cara mengekspresikan emosinya secara tepat sehingga emosinya dapat dikontrol dan banyak memberikan banyak manfaat dalam kehidupan sehari-hari. Hasil dari beberapa studi analisis mengidentifikasikan bahwa faktor dari luar yang berpengaruh terhadap OCB diantaranya adalah Kepuasan Kerja, karyawan yang merasa puas akan memiliki kinerja dan kehadiran yang lebih baik dari pada karyawan yang kepuasan kerjanya rendah (Luthans, 2006 dalam Sumiyarsih 2012). Kepuasan Kerja dan Kecerdasan Emosional yang tinggi dapat mendorong seseorang untuk bekerja lebih baik dan menumbuhkan perilaku OCB yang pada akhirnya akan mewujudkan tujuan dan kesuksesan organisasi. Hasil penelitian ini sejalan dengan penelitian yang dilakukan oleh Wiwik Sumiyarsih dkk tahun 2012 dan Farahiyah dkk Tahun 2016.

7) Hipotesis 7 " Kepuasan Kerja memediasi Motivasi Kerja terhadap Organizational Citizenship Behavior (OCB)".

Hasil Pengujian Hipotesis 2 menunjukkan bahwa Motivasi Kerja berpengaruh positif terhadap Kepuasan Kerja, hasil pengujian Hipotesis 5 juga menunjukkan bahwa Motivasi Kerja berpengaruh signifikan terhadap Organizational Citizenship Behavior (OCB). Hasil pengujian antar variabel bersifat positif dan signifikan sehingga terjadi mediasi, sehingga Hipotesis 7 di terima.

Dapat disimpulkan bahwa Karyawan dengan kepuasan kerja yang tinggi akan 
memiliki sikap sesuai dengan aspek dan karakteristik yaitu memiliki sikap tenang dalam bekerja, mempunyai motivasi kerja yang tinggi dalam menghadapi pekerjaan yang banyak dll, sehingga karyawan memiliki perilaku OCB dalam bekerja karena kepuasan yang tinggi akan mendorong seorang karyawan memiliki perilaku menolong sesama karyawan bahkan untuk membantu organisasi lebih maju. Karyawan dengan motivasi yang tinggi, akan meningkatkan kepuasan dan lebih terdorong untuk berpartisipasi dalam pekerjaannya, berkomitmen terhadap kelompok maupun organisasi serta memiliki inisiatif dan optimisme yang tinggi (Goleman, 2005 dalam Sumiyarsih, 2012). Hasil penelitian ini sejalan dengan penelitian yang dilakukan oleh Wiwik Sumiyarsih dkk (2012).

\section{PENUTUP}

\section{- Kesimpulan}

1. Berdasarkan hasil Uji Hipotesis dan pembahasan seperti yang telah diuraikan pada bab sebelumnya maka diperoleh kesimpulan sebagai berikut :

a.Kecerdasan emosional berpengaruh signifikan terhadap kepuasan kerja dengan demikian dapat disimpulkan $\mathrm{H}_{1}$ terbukti.

b. Motivasi berpengaruh signifikan terhadap kepuasan kerja, dengan demikian dapat disimpulkan $\mathrm{H}_{2}$ terbukti.

c. Kepuasan kerja berpengaruh signifikan terhadap Organizational Citizenship Behavior (OCB), dengan demikian dapat disimpulkan $\mathrm{H} 3$ terbukti.

d. Kecerdasan Emosional berpengaruh signifikan terhadap Organizational Citizenship Behavior (OCB), dengan demikian dapat disimpulkan $\mathrm{H} 4$ terbukti.

e. Motivasi Kerja berpengaruh signifikan terhadap Organizational Citizenship Behavior (OCB), dengan demikian dapat disimpulkan $\mathrm{H} 5$ terbukti.

f. Kepuasan Kerja memediasi Kecerdasan Emosional terhadap Organizational Citizenship Behavior (OCB), dengan demikian dapat disimpulkan H6 terbukti.

g. Kepuasan Kerja memediasi Motivasi Kerja terhadap Organizational Citizenship Behavior (OCB), dengan demikian dapat disimpulkan $\mathrm{H} 7$ terbukti.
2. Hasil Uji $F$ diketahui besarnya nilai $F$ diketahui besarnya nilai $\mathrm{F}=125,764$ dengan nilai signifikansi $0,000<0,05$. Sehingga dapat disimpulkan secara bersama-sama variabel Kecerdasan Emosional, Motivasi Kerja dan Kepuasan Kerja berpengaruh signifikan terhadap Organizational Citizenship Behavior (OCB).

3. Nilai R2 total sebesar 0,798 dapat diartikan variasi OCB Karyawan di PT.Pos Indonesia Persero Surakarta dijelaskan oleh variabel Kecerdasan Emosional, Motivasi Kerja dan Kepuasan Kerja sebesar $79,8 \%$ dan sisanya 20,2 \% dijelaskan oleh variabel-variabel lain di luar variabel-variabel yang diteliti dalam penelitian ini.

\section{- Saran dan Rekomendasi}

Berdasarkan hasil penelitian dan keterbatasan diatas, maka saran yang dapat di sampaikan antara lain :

1. Kecerdasan emosional merupakan hal yang sangat penting sebaiknya karyawan perlu meningkatkan kemampuan dalam mengelola kecerdasan emosional melalui pelatihan, hal ini dilakukan agar karyawan lebih bisa mengembangkan diri dan menunjang semangat kerja sehingga dapat meningkatkan kemampuan dan produktivitas karyawan dalam menjalankan tugas.

2. Motivasi Kerja perlu di tingkatkan, atasan sebaiknya lebih memotivasi karyawan. Motivasi kerja merupakan suatu proses yang merujuk kepada munculnya dorongan untuk melakukan aktivitas pekerjaan. Individu yang termotivasi dan puas a cenderung akan melakukan pekerjaan yang lebih lagi, bahkan melakukan pekerjaan yang bukan menjadi tanggungjawabnya.

3. Pada variabel kepuasan kerja, perusahaan sebaiknya memberikan kesempatan promosi kepada karyawan untuk meningkatkan kepuasan kerja mereka, karena dengan promosi dapat meningkatkan status sosial yang lebih tinggi dan pertumbuhan pribadi yang lebih baik. Karyawan yang di berikan kesempatan promosi secara adil kemungkinan besar akan mengalami kepuasan kerja dari pekerjaan mereka. 
4. Pada varaibel organizational citizenship behavior (OCB), perilaku sukarela atau OCB sebaiknya harus terus di tingkatkan karena OCB memiliki banyak manfaat bagi kemajuan perusahaan antara lain: dapat meningkatkan produktivitas kerja, dapat meningkatkan produktivitas pimpinan, menghemat sumber daya yang dimiliki manajemen / organisasi atau lembaga secara keseluruhan serta OCB juga dapat meningkatkan kemampuan organisasi untuk beradaptasi dengan perubahan lingkungan dll.

5. Lingkup penelitian sebaiknya di perluas, baik meliputi wilayah penelitian maupun obyek penelitian sehingga hasil penelitian dapat lebih representatif atau dapat digeneralisasi untuk penelitian lain, untuk penelitian selanjutnya sebaiknya menggunakan metode wawancara atau observasi langsung kepada responden agar tidak terjadi bias atas jawaban responden.

\section{DAFTAR PUSTAKA}

Berry, L.M. 1998. Psychology at work. New York: McGraw-Hill Internasional.

Cooper RK \& Ayman Sawaf. 2001. Executive $E Q$ : Kecerdasan Emosional dalam Kepemimpinan dan Organisasi. Jakarta : PT Gramedia Pustaka Utama.

Ghozali, Imam, and Fuad. 2008. Structural Equation Modeling: Teori, Konsep dan Aplikasi Dengan Program Lisrel 8.0. Semarang: Badan Penerbit UNDIP

Goleman, D. 2005. Working With Emotional Intelligence: Kecerdasan Emosi Untuk Mencapai Puncak Prestasi. Alih Bahasa: Alex Tri K. Widodo. Jakarta : PT. Gramedia Pustaka Utama.

Hair, J.R. Anderson, R.E, Tatham. R.L \& Black. W.C. 1998. Multivariate Data Analysis. Upper Saddle River: Prentice Hall International Inc.

Hariandja, Tua Efendi (2002). Manajemen Sumber Daya Manusia: Pengadaan Pengembangan Pengkompensasian Dan Peningkatan Produktivitas Pegawai. Jakarta: Penerbit PT. Grasindo.

Hasibuan, Malayu SP. 2009. Manajemen: Dasar Pengertian, dan Masalah. Jakarta: PT. Bumi Aksara.

Luthans, F. (2006). Organizational Behavior. New York: McGraw-Hill.

Mahesa Deewar (2010). Analisis Pengaruh Motivasi dan Kepuasan Kerja Terhadap
Kinerja Karyawan dengan Lama Bekerja sebagai Variabel Moderating. Fakultas Ekonomi: Universitas Deponegoro.

Maynard, Douglas C., Daniel C. Field. (2011) Unemployment. Pshicological,13 Economic, and Social Chalenge. London: Springer

Organ, D.W., Podsakoff P. M.,Mackenzie, S.B. 2006. Organizational Citizenship Behavior :its Nature, Antecedents and Consequences. Sage Publication.

Patton, P. 1998. EQ Di Tempat Kerja. Jakarta : Pustaka Delapratasa.

Podsakoff, P.S Mackenzie, B.Paine, \& D. Bachrach (2000). Organizational Citizenship Behavior: Acritical Review Of The Theoretical And Empirical Literature And Suggestions For Future Reseach. Journal of management, Vol. 26, No.3, pp.513-563.

Robbins, Stephen P \& Timothy A Judge. 2008. Perilaku Organisasi Edisi Ke-12. Jakarta: Salemba Empat.

Riantini Farahiyah Eki dkk. (2016). Pengaruh Motivasi, Disiplin dan Kepuasan Kerja Terhadap Organizational Citizenship Behavior Tenaga Outsourcing di Dinas Pendapatan dan Pengelolaan Keuangan Kota Surabaya. Dinamika Global: Rebranding Keunggulan Kompetitif Berbasis Kearifan Lokal. ISBN 987-60260569-2-4.

Sarisusantini K.(2012). Meningkatkan Leader MemberExchange dari bawahan dan kepuasan terhadap atasan melalui pelatiahan coaching bagi penyelia PT.X. Tesis, Fakultas Psikologi, Universitas Indonesia, Depok.

Sekaran, U. 2006. Research Methods For Business. Edisi 4, Buku 1, Jakarta: Salemba Empat.

Siagian, Sondang P. (2002). Kiat meningkatkan Produktivitas Kerja. Jakarta: PT. Rineka Cipta

Sumiyarsih, W., Mujiasih E \& Ariati J. 2012. Hubungan antara Kecerdasan Emosional dengan Organizational Citizenship Behavior (OCB) pada Karyawan $C V$. Aneka Ilmu Semarang. Jurnal Psikologi Undip. Vol.11, No.1. Halaman: 19-27.

Susetyo Yuwono dkk. (2014). Hubungan Antara Motivasi Kerja dan Kepuasan Kerja dengan Organizational Citizenship Behavior (OCB). Seminar Nasional dan Call for paper (Sancall 2014), ISBN:987602-70429-1-9. Hlm. 444-451 